\section{Nødvendig oppdatering innen vanskelig fagområde}

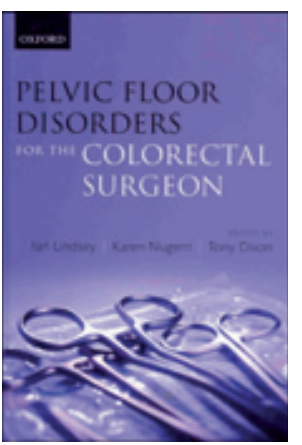

lan Lindsay, Karen Nugent, Tony Dixon, red. Pelvic floor disorders for the colorectal surgeon

278 s, tab, ill. Oxford: Oxford University Press, 2010. Pris GBP 50

ISBN 978-0-19-957962-4

Ikke bare kolorektalkirurger kan ha nytte av denne utgivelsen, den bør også ha mye å gi urologer, gynekologer og andre med spesiell interesse for bekkenbunnsproblemer. Gynekologiske og urologiske problemstillinger behandles imidlertid ikke. I så måte er den litt snever, og jeg savner litt av helhetssynet, selv om det kan skimtes her og der.

Dette er en litt utradisjonelt oppbygd lærebok i tre deler - tilnærminger, kliniske syndromer og operasjonsteknikker. Den består av 24 kapitler med egne forfattere, derfor blir det nødvendigvis litt gjentakelser, men det gjør den ikke mindre leseverdig. Forfatterne er hovedsakelig britiske, og i deler bærer boken preg av å være litt lokal, dvs. den gjenspeiler tradisjonen ved forfatternes institusjoner. Ikke desto mindre hevdes det at innholdet er et oppgjør med gamle tradisjoner og at det gjenspeiler en moderne patofysiologisk tenkemåte.

Teksten er lettlest og layouten moderne, med faktabokser, nøkkelpunkter og redaktørenes sammenfatning av enkeltkapitlene. Helhetsinntrykket hadde nok blitt atskillig bedre hvis illustrasjonene og fotografiene hadde vært i farger. En del av operasjonsbildene blir svært vanskelige å fortolke i gråskalaer.

Forfatternes ambisjoner om å være oppdatert og moderne gjør denne utgivelsen litt provoserende. Laparoskopisk ventral rektopeksi beskrives som foretrukket metode for pasienter med internt rektalprolaps. Det kan jo godt være at dette er og blir den metoden vi kommer til å foretrekke, men erfaringene med den er jo til nå ganske begrenset. Med tanke på at det allerede er beskrevet godt over 100 forskjellige metoder for operasjon av invaginasjon/prolaps, kunne kanskje litt mindre skråsikkerhet fra forfatternes side vært på sin plass. Det legges mye mer vekt på defekografiundersøkelser, funn av internt prolaps får nå en renessanse og forfatterne vil med dette forklare både smerter, inkontinens og obstruert defekasjon. Hos mange pasienter er det nok en viktig del av symptomkomplekset, men jeg savner diskusjonen om hva som er høna og hva som er egget. Fra mitt eget litt konservative ståsted aner jeg en overentusiasme for de seneste teknikkene, spesielt da den ventrale rektopeksien og kanskje enda mer STARR-metoden (stapled transanal rectal resection). Dette er en metode som mange med meg synes er sterkt oppskrytt - tiden får vise om det er riktig eller ei.

Med disse små reservasjonene må det sies at Pelvic floor disorders for the colorectal surgeon gir en glimrende oversikt over anoproktologiske funksjonsforstyrrelser - alt fra hvordan man bygger opp en anoproktologisk enhet og hvilke utredninger som er aktuelle til konservative og kirurgiske behandlingstiltak. Den gir gode praktiske råd og behandlingsalgoritmer på et felt der veldig mye fremdeles er uavklart.

\section{Tom Øresland}

Avdeling for gastroenterologisk kirurgi

Akershus universitetssykehus

\section{Håndbok for kolorektalkirurger}

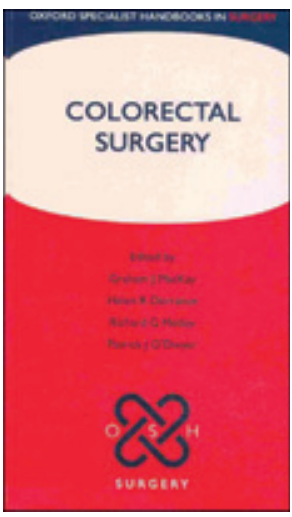

Graham J. Mackay, Helen R. Dorrance, Richard G. Molloy et al, red. Colorectal surgery 602 s, tab, ill. Oxford: Oxford University Press, 2010. Pris GBP 45 ISBN 978-0-19-957177-2

Denne utgivelsen inngår i serien Oxford Specialist Handbooks og er beregnet på frakkelommen til assistentleger i spesialisering. Colorectal surgery er laget for den britiske spesialiteten i kolorektal kirurgi og er ment å dekke pensumet for den avsluttende spesialisteksamenen.

Den byr på et omfattende spektrum fra anatomi, fysiologi til utredning, deriblant litt om f.eks. anal manometri og defekografi. Det er kapitler om vanlige problemstillinger som man møter på poliklinikken og hos innlagte pasienter, men også mer sjeldne lidelser. De vanligste sykdommene er forholdsvis omfattende dekket, det er f.eks. 80 sider om malign kolorektal sykdom og 80 sider om inflammatorisk tarmsykdom. Men også mindre temaer som obstruktiv defekasjon, analstenose og rectumprolaps er med. Det er en egen sesjon om akutt kolorektal kirurgi, som bl.a. berører ileus, colonperforasjon, anastomoselekkasje og akutte colonblødninger. I slutten kommer det strektegninger av de vanligst brukte kolorektale inngrep samt et litt spennende kapittel om våre kanskje nærmeste kirurgiske kolleger når det gjelder bekkenet - urologene og gynekologene. Man går gjennom de vanligst tilgrensende temaer som f.eks. endometriose, salpingitt, ureterskader og ulike kreftsykdommer i bekkenet.

Colorectal surgery er solid innbundet, den er myk å ha i en frakkelomme og for øvrig også rikholdig illustrert med over 200 figurer.

Alt i alt vil jeg si at dette er en bok tettpakket med oppdatert, komprimert informasjon om det meste innenfor det kolorektale fagfeltet. Målgruppen i Norge blir først og fremst assistentleger som skal bli gastrokirurger. Også for noe mer erfarne kolleger kan dette være et greit oppslagsverk når man raskt trenger kortversjonen innenfor et tema. Den dekker det viktigste av det man som assistentlege trenger å vite om nedre gastrokirurgi, og praksis i Storbritannia virker å være temmelig lik den norske. Mangelen er at den ikke dekker øvre gastrokirurgi. Men den dekker et imponerende antall ulike temaer kort og konsist, så den kan absolutt brukes til å slå opp i kjapt i ulike sammenhenger. Den er velskrevet, går rett til sakens kjerne og inneholder noen få gode nøkkelreferanser til hvert tema. Colorectal surgery kan være god å ha på avdelingen dersom man skal oppdatere sin egen metodebok.

Bjørn Steinar Olden Nedrebø

Seksjon for gastrokirurgi

Stavanger universitetssjukehus 